\title{
Contemporary Congolese Literature as World Literature
}

\author{
Julien Jeusette | ORCID: 0000-0002-2631-8450 \\ Università degli Studi di Milano, Milan, Italy \\ Julien.jeusette@unimi.it
}

Silvia Riva | ORCID: 0000-0002-0100-0569

Università degli Studi di Milano, Milan, Italy

silvia.riva@unimi.it

"Penser le monde à partir de l'Afrique" (Mbembe and Sarr 379) - to think the world from the perspective of Africa. ${ }^{1}$ Achille Mbembe's article, which concludes the volume Écrire l'Afrique-Monde, advocates for a shift: not only to stop viewing Africa as a peripheral and marginalized continent but also to imagine, create, and reflect the world from an African point of view. Mbembe goes further and considers, more boldly, that "there is not a part of the world whose history does not contain somewhere an African dimension"2 (385). Moreover, as he declares with Felwine Sarr in the introduction of the book, "there is no longer any African or diasporic question that does not at the same time refer to a planetary question" (12). The world is intertwined, and Africa is one of its moving centers. In this regard, the Congo DRC, formerly the Belgian Congo, with its abundance of natural resources, is often viewed as one of the primary hubs enabling the world markets to function. "The Congo is at the center of the world since 1884 [the date of the Berlin Conference]," declares the writer Fiston Mwanza Mujila (Maveau). This special issue endorses this perspective but departs from both an economic focus and the vision of Congo as a "failed State" (Nay 326) to consider Congolese literary production at the crossing of worlds and languages, mainly contemporary literature published after 2000.

Since the beginning of the twenty-first century, there has been an "explosion of the editorial demand in African literature" (Ducas 207), and D RC writers

1 We hereby warmly thank Matt Reeck for his thorough carefulness in proofreading and editing the articles in this issue.

2 All translations of French quotes are ours. 
are contributing to this uptick, not only through the primary circuits of consecration but also through numerous local initiatives, including those begun by small publishing houses, large electronic portals (the growing influence of African Literature blogs and websites, as in Anglophone Africa ${ }^{3}$ ), book fairs (the "Kinshasa Fête du Livre," an event launched in 2013 that is becoming increasingly successful, as well as the "Salon du Livre du Kongo-Central," dedicated since 2021 to literature in the Congolese national languages), and initiatives aimed to promote reading and the circulation of old and new books (Gombo).

Based upon the usual way of declaring an author's success, that is, the literary prize, it is clear that a new generation of Congolese authors is internationally acclaimed. From authors such as In Koli Jean Bofane to Blaise Ndala, from Sinzo Aanza to Fiston Mwanza Mujila and Richard Ali A Mutu, many Congolese authors have recently been translated into numerous languages. Their works, like themselves, are now circulating far beyond their context of origin, and there is no doubt that they are gaining from these travels. That is why we consider it urgent to read them from the perspective of world literature, a perspective that could benefit from a broadening of critical views in order to usher in a "planetary" point of view on literature.

To introduce this special issue, we will address three questions that indicate the importance of analyzing this contemporary literary production from a world literature perspective, using it not as a dogma, but as a possible access key.

\section{Circulation}

First, the question of circulation. When looking at today's widely recognized writers from the Congo, the heterogeneity of their diasporic trajectories is striking. While Richard Ali A Mutu and Sinzo Aanza live in Kinshasa (the latter being a native of the Great Lakes Region); In Koli Jean Bofane and Lisette Lombé live in Belgium; Fiston Mwanza Mujila in Austria; Blaise Ndala in Canada; Marc-Antoine Vumilia in Sweden; Muepu Muamba in Germany; JJ Bola in the UK; and Annie Lulu (born in Romania) in France - to mention just a few. Their editorial strategies are interesting to follow, first of all, because they complicate the idea that Francophone writers seek to publish (and to live) in Paris (or in Brussels). These authors' performances and texts - whether novels,

3 Examples include the Nigerian website Naija Stories, committed to promoting Nigerian fiction, or the blog The Chimurenga Chronic, which is based in Africa and has a global reach. 
poetry, theater, or exhibitions - have been published or staged in a variety of places, and interestingly, except for Fiston Mwanza Mujila's Tram 83, very few are published in the French capital. In Koli Jean Bofane's novels are published in France, but by Actes Sud in Arles. Richard Ali A Mutu's Ebamba, Kinshasa Makambo, was first published in Brussels in Lingala, before being translated into English - without passing through the French language. Blaise Ndala's novels, which are celebrated in Quebec (and translated in foreign languages such as Russian), were hardly known outside Canada until his recent publication with Le Seuil of Dans le Ventre du Congo (In the Womb of the Congo) in 2021. These examples indicate that contemporary African literary circulation is less predictable and much more deterritorialized than in the twentieth century. ${ }^{4}$

As a consequence, it seems fundamental to interrogate these authors' "significant geographies," the phrase proposed by Karima Laachir, Sara Marzagora, and Francesca Orsini, in order to complicate the center/periphery approach of world literature: "By significant (as in 'significant others') we mean trajectories and imaginaries that are recurrent and/or that matter to actors and texts" (294). In a diasporic group as diverse as the Congolese writers mentioned here, it is of course difficult to point out recurrent schemes and narratives that matter - we might thus be forced to consider every text, every writer's significant geography. Nevertheless, this diversity of psychic and geographical trajectories is itself an antidote to the idea of a unified, monological globalized world: the more circulation, the more diverse the significant geographies become. Yet, in the case of Congolese writers, especially the older generation, the significant "library," or archive, is often constituted by a mix of African and Western sources. The poet Patrick Mudekereza, for instance, states in an interview (Aiello 2020) that his two major influences are George Brassens's songs and the zangazanga funeral laments of Katanga; he writes poems in French, Swahili, and Lingala. To take another example, In Koli Jean Bofane writes in "Le lecteur-fantôme" ("The Ghostly Reader"), a short autobiographical essay written for the "Global Congo" issue of the journal Continents manuscrits:

You must remember that I was born in the midst of colonization. The whites squatted everything at that time, and especially the family's library. Among the writers and thinkers, one of them quite naturally attracted my attention. It was Zola Émile. The word zola, in Lingala, means "love," and the title of the book was Nana, a typical Congolese name. I was convinced

4 Unfortunately, however, the circulation of the writers is still dependent on old hierarchies and border controls: in July 2017, for instance, Richard Ali A Mutu did not get a visa to present his book with Ngũgĩ wa Thiong'o in the United States, and he had to speak via Skype. (French) 
a fellow countryman had turned his back on the concepts of slavery and colonialism to raise himself - I ignored through which miracle - above the third shelf of the bookcase, like the other writers that had just granted me a new kind of independence. ("Le lecteur")

Of course, Zola is a French author, as Bofane quickly understands, but this linguistic scam (arnaque) leads him to read high-brow literature and to desire to write himself, in order to place a real Congolese name on the top of the bookshelf. Like world literature, "significant geographies" are constantly evolving, and the writers are at once the subjects and the agents of this change.

\section{2 \\ Multilingualism and Translation}

This brings us to our second point: the question of languages and translation. The Congolese context is a rare case of multilingualism. French is the official language of the country, and the DRC is considered the most populous French-speaking country in the world: in 2018, 42.5 million Congolese, or $5^{\circ} .6$ percent of the country's population, were able to read and write French ("Combien de francophones"). French is followed by four national languages: Swahili, Tshiluba, Lingala, and Kikongo, but linguists have noted the presence of more than two hundred languages over the entire territory, most of them oral (9 percent of the nearly five thousand languages in use on the planet (AFP)). During the time of the Congo Free State (1885-1908) under the personal control of King Leopold II, and even during the time of the Belgian rule (1908-1960), Dutch was the second official language of the colony, and its archives were bilingual: French and Dutch. Some traces of this presence remain today. Finally, due to the historical-geographical proximity to Angola, one can also find groups of Lusophone speakers in the country.

The writers of the diaspora are (so far) the most visible on an international level because they have entered the global literary market and because their texts have been translated. One should not neglect, however, the more local literary productions that circulate throughout the Congolese territory. The majority of non-Francophone literature can be found within the national languages, even if, during the colonial era, some minor local languages such as Lomongo received some attention through periodicals (often supported by the Belgian administration or the missionary institutions) (Riva 23).

As far as the four national languages are concerned, the Tshiluba culture, with more than six million speakers between the provinces of Kasai and Katanga, has given rise to many important authors, such as Pius Ngandu 
Nkashama, who is also one of the pioneers of literary research in African languages, or Joachim Kadima Kadiangandu, who created a new form of orality through the rewriting of myths. Tshiluba literature has its own "Tabalayi Literary Prize," and for a long time, Glopro Editions, edited by José Tshisungu wa Tshisungu, ensured the circulation of those works from Sudbury, Canada.

Lingala is the most commonly spoken language in the capital, Kinshasa, and has about nine million speakers spread across Africa. Bienvenu Sene Mongaba, the founder of Mabiki Editions (Brussels and Kinshasa), is currently promoting the transmission and use of Lingala through novels, linguistic studies, and science textbooks. Author of several novels written in Lingala (Fwa-Ku-MputuMourir en Europe, Bokobandela, Sanza nguma, and Basalela babwaka), he noted in a 2010 conference (Mongaba) held at the University of South Africa that there were about one hundred literary works (masoló bakomá) written in Lingala. The production of strip cartoons (masoló badesiná) is even more important. ${ }^{5}$ In the last decade, this process has accelerated, and the potential audience in Lingala is increasingly important - even more so as the boundaries of its diffusion are widened through translation. For instance, Bienvenu Sene Mongaba and Sara Sene translated Richard Ali A Mutu's Ebamba Kinshasa Makambo (lisolo) into English with the title Mr. Fix-It. It was first published in the Africa39 anthology with a preface by Wole Soyinka (Allfrey 2014), thus violating the implicit expectation that writers of former Francophone colonies are unerringly attracted to Brussels, Paris, or Montréal.

Finally, with regard to the diaspora, we must add that even in colonial times, the languages used to narrate migratory experience were not necessarily French, Flemish, or local languages but, more simply, languages learned while emigrating. The first autobiographical Congolese novel, in that sense, was written in Spanish by Francisco Jose Mopila, his 1949 Memorias de un Congolés (ensayo de auto-biografía) (Memories of a Congolese: Autobiographical Essay). Many others followed, and there are cases of Congolese writings in Italian, as in the case of Paul Bakolo Ngoi, ${ }^{6}$ grandson of a Lomongo-speaking writer of the same name and author of an extensive production of children's books.

From this brief overview, it becomes clear that to grasp the richness of this literature, ${ }^{7}$ multilingual research collaboration is needed, and it would be fundamental to bring (through funding) these corpora into dialogue with one another.

5 For a list of these works, as well as an introduction to Lingala literature, see Mongaba 2011. As far as the importance of cartoon strips in DRC, see Federici 2019.

6 His most successful novel, due to its editorial positioning and soccer theme, is Colpo di testa (2003).

7 For a schematic overview in English of all written Congolese languages, literatures, and their 
The last point we will address is the representation of globalization and world interactions in contemporary Congolese texts. This theme is a leitmotif running through recent major novels, from Blaise Ndala's Sans Capote ni kalachnikov (this novel will soon be translated into English, published by Véhicule Press in Canada) and Le Ventre du Congo, to In Koli Jean Bofane's Congo Inc. and Fiston Mwanza Mujila's Tram 83. In their quest to gain economic or symbolic status, the ambivalent characters of these texts are all concerned by the dialectics of periphery and center(s), of local and global, of failure and success - necessarily on an international or transcontinental scale (this is at least what the characters believe at the beginning of these novels). The presence of this theme in contemporary Congolese literature may be an indication of the globalized environment in which the characters are at once victims and active forces, but also a symptom of the Congo's central place in global exchanges. Yet this issue is not new. It can be traced back to Georges Ngal's Giambatista Viko ou, Le Viol du Discours africain (1975), a novel analyzed by David Damrosch in his book What Is World Literature? (2003).

Ngal's main character, who reappears in L'errance (Wandering, 1979), is looking for the best strategy to gain celebrity and conquer the world with his intellect. Translation is the key, and "Chinese is ten times better" (Ngal 114) than all the other languages. Written in the local context of the "return to authenticity" campaign promoted by the Mobutu regime, Ngal's novel was partially parodic, and intended as a polemic against a specific kind of intellectual (V.Y. Mudimbe, aiming at fostering a new science for Africa). As early as the 1970s, Mudimbe spoke about themes that would become urgent decades later: "communication and identity in a globalizing world" (Damrosch 116); the necessity to find intercultural means of allowing Africans to overcome the particularisms of identity and its drifts (Ngal and Mudimbe witnessed one of the first Rwandan genocide, in 1954); and the need to escape cultural neocolonialism. Regarding this last point, let's consider the contemporaneity of the following excerpt from Mudimbe's essay "L' Autre Face du royaume. Une introduction à la critique des langages en folie" ("The Other Side of the Kingdom: An Introduction to the Critique of Languages of Insanity"), published in Switzerland in 1973, two years before the publication of Giambatista Viko, whose name refers to the Italian philosopher who in 1725 undertook the writing of a new science (Scienza nuova):

genres, see Crispin Maalu-Bungi 2008. Regarding Congolese literature in Kiswahili, see Aiello 2020 and Le Lay 2009. 
Ethnology [is] unthinkable as a 'science' believing that it can [...] survive for a long time the criticism that will rise more and more violently, singularly of its 'objects'; [...] but I also see it too alive, fluctuating, diverse, of a remarkable opportunism for me to announce its death. Alive or dead, [ethnology] concerns me only as an expression of a certain ideological practice: it is indeed, a discourse stuck in an order which founds it and explains it. ${ }^{8}$

It is clear that, as Damrosch writes, Giambatista Viko "can be seen as a pathbreaking work both of and about world literature in a world of unequal power relations, where vanity, self-defensiveness, and a will to power pervade every group" (116). And as I noted in 2006 about Ngal's book:

At the end of the journey, [the characters] no longer conceive of writing as a hybrid mix of traditional techniques adapted to a discourse that slavishly follows the Western model. On the contrary, [...] Giambatista realizes that a particular appropriation (univocal and definitive) of the original language is impossible, but that, precisely because it is original, it speaks through all the languages and it lies at their core. At the end of his long initiation, he thus declares: "Indeed we speak several languages $[\ldots]$, they are the deep and differential waters which constitute the diversity of humanity in its various figures."

RIVA 181

In his seminal book, Damrosch regretted the fact that, despite its richness, this particular Congolese novel was "almost entirely neglected by scholars as well as general readers" (116). It can also be added that a certain African philosophy, with which the works of African writers have been imbued for at least fifty years, has also been neglected by critics for a long time. Now the new generation of Congolese writers follows - albeit with different poetic means and political goals - Georges Ngal's (and V.Y. Mudimbe's) pioneering interrogations. On a critical level, Achille Mbembe and Felwine Sarr are also following this

8 “[L'] éthnologie [est] impensable comme 'science' pour croire qu' elle puisse [...] survivre longtemps à la critique qui montera de plus en plus violente, singulièrement de ses 'objets'; [...] mais je la vois aussi bien vivante, fluctuante, diverse, d'un opportunisme remarquable pour m' engager à annoncer sa mort. C' est que vivante ou morte, elle ne me concerne que comme expression d' une certaine pratique idéologique: elle est en effet, discours englué dans un ordre qui la fonde et l' explique." 
path. With this special issue, our goal is to promote contemporary Congolese literature, laying out the richness of its production, the importance of its contextualization, and stressing its planetary agency.

The five essays published here address contemporary Congolese literature from a world literature perspective, focussing on circulation, translation, multilingualism, and the interpretation of "worldliness."

Xavier Garnier's article "Writings of the Subsoil in the Contemporary Congolese Novel" deals with narratives that thematize mining and excavation and analyzes how the Congo's subsoil can be perceived as a vector of aggressive globalization. His analysis illustrates how the imaginary of mining has given rise to a "super-tanker literature, a cargo-plane literature, a pipeline literature," each of which uses both the metaphors of drilling and the notion of an ecological Critical Zone to talk about the reappropriation of Congolese land.

Susanne Gehrmann's article “Congolese Child Soldier Narratives for Global and Local Audiences: From Testimony to Reconciliation" focuses on a specific corpus in African literary critique: the writings of and about former child soldiers. Comparing different testimonies published in France and the Congo, Gehrmann highlights the different editorial frames and narrative strategies used to address local and global audiences.

Duncan M. Yoon's article "Figuring Africa and China: Congolese Literary Imaginaries of the PRC" examines the evolution of the representation of China in Congolese literature from the Cold War (and Maoism) to the present. Fiction is presented as a privileged lens through which to figure and understand the complexities of Africa-China relations in recent history.

Françoise Naudillon's article "Popular Art Forms in the DRC: Practices and Peripheries" broadens the very notion of "literature" and shows the vitality of local forms that transgress and escape the literary canon. Naudillon shows that marginalized productions like fanzines, small-run comic strips, detective novels, and dime novels are widely read and are vectors of social change.

Silvia Riva's "Congolese Literature as Part of Planetary Literature," the last article of the issue, starts from the necessity of recasting (reprendre, using Mudimbe's term) scholarship into an awareness of the multilingual productions and exchanges (cosmopolitan and vernacular, written and oral) that were never fully interrupted by colonization. The metaphor of the "Third Landscape," borrowed from Gilles Clément, allows Riva to account for contact phenomena between different literary bodies and to present the idea of "planetary literature" as a way of envisaging the interconnection among literatures taking care of the world. 


\section{Works Cited}

AFP. “En RDC, la nostalgie des langues perdues." L'Express 28 Apr. 2017. Web. 25 Apr. 2021.

Aiello, Flavia, and Roberto Gaudioso. "Les transgressions poétiques d'un auteur swahiliphone de Lubumbashi: Patrick Mudekereza." In "Global Congo." Ed. Silvia Riva. Continents manuscrits 15 (2020). Web. 15 Apr. 2021.

Allfrey, Ellah Wakatama, ed. Africa39: New Writing from Africa South of the Sahara. London: Bloomsbury, 2014.

Bofane, In Koli Jean. “Le lecteur-fantôme.” In “Global Congo.” Ed. Silvia Riva. Continents manuscrits 15 (2020). Web. 15 Apr. 2021.

Damrosch, David. What Is World Literature? Princeton: Princeton UP, 2003.

Ducas, Sylvie. La Littérature à quel(s) prix? Histoire des prix littéraires. Paris: La Découverte, 2013 .

Federici, Sandra. L'entrance des auteurs africains dans le champ de la bande dessinée européenne de la langue française (1978-2016). Preface by Pierre Halen and Silvia Riva. Paris: L'Harmattan, 2019.

French, Agatha. "Congolese author couldn't get a visa." Los Angeles Times 31 Jul. 2017. Web. 15 Apr. 2021.

Gombo, Christian. "Oui, le Congo est un centre littéraire." In “Global Congo." Ed. Silvia Riva. Continents manuscrits 15 (2020). Web. 15 Apr. 2021.

Kadiangandu, Joachim Kadima. Mikombu wa kalewu: nkayenda mudifuke. Paris: Giraf, 1999. Laachir, Karima, Sara Marzagora, and Francesca Orsini. "Significant Geographies: In Lieu of World Literature." Journal of World Literature 3:3 (2018), 290-310.

Le Lay, Maëline. "Les langues d'écriture à Lubumbashi: une littérature diglossique?" Études littéraires africaines 27 (2009), 55-64.

Maalu-Bungi, Crispin. "Written Literature in Congolese Languages: Origin and Principal Genres." In Beyond the Language Issue: The Production, Mediation and Reception of Creative Writing in African Languages. Eds. Anya Oed and Uta Reuster-Jahn. Köln: Rüdiger Köppe Verlag, 2008.

Maveau, Roger. "Kinshasa est une somme de possibles." Le Point Afrique 28 Oct. 2020. Web. 10 Apr. 2021.

Mbembe, Achille and Felwine Sarr, eds. Ecrire l'Afrique-monde. Paris: Philippe Rey, 2017. Mongaba, Bienvenu Sene. "La littérature congolaise écrite en lingala." International Conference on Congolese Post-colonial Literature, unpublished text, 2011. https://core .ac.uk/download/pdf/55827623.pdf. Web. 10 Jan. 2021.

Mudimbe, V.Y. L'Autre Face du royaume. Une introduction à la critique des langages en folie. Lausanne: L'Age d'homme, 1973.

Nay, Olivier. "Fragile and Failed States: Critical Perspectives on Conceptual Hybrids." International Political Science Review 34:3 (2013), 326-41. 
Ngal, Georges. Giambatista Viko, ou le viol du discours africain. Paris: Alpha-Omega, 1975. Ngal, Georges. L'errance, Yaoundé: CLE, 1979.

Ngoi, Paul Bakolo. Littérature bantoue. Lomongo-français, N.p.: Imprimerie M.C. Muka: n.d.

Ngoi Jr., Paul Bakolo. Colpo di testa. Milan: Fabbri Editori, 2003.

Nkashama, Pius Ngandu. Sémantique et morphologie du verbe en ciluba. Paris: L'Harmattan, 1999.

Riva, Silvia. Nouvelle Histoire de la Littérature du Congo-Kinshasa. Paris: L'Harmattan, 2006.

Tshisungu wa Tshisungu, José. “Que dit la littérature en ciluba?” Semences (blog) 26 Dec. 2015. Web. 15 Apr. 2021.

"Combien de francophones dans le monde?" Organisation internationale de la francophonie. http://observatoire.francophonie.org/qui-parle-francais-dans-le-monde/. Web. 3Jan. 2021. 